This item was submitted to Loughborough's Research Repository by the author.

Items in Figshare are protected by copyright, with all rights reserved, unless otherwise indicated.

\title{
High rate deposition of thin film CdTe solar cells by pulsed dc magnetron sputtering
}

PLEASE CITE THE PUBLISHED VERSION

http://www.mrs.org/fall2015/

\section{PUBLISHER}

(C) Materials Research Society

\section{VERSION}

AM (Accepted Manuscript)

\section{PUBLISHER STATEMENT}

This work is made available according to the conditions of the Creative Commons Attribution-NonCommercialNoDerivatives 4.0 International (CC BY-NC-ND 4.0) licence. Full details of this licence are available at: https://creativecommons.org/licenses/by-nc-nd/4.0/

\section{LICENCE}

CC BY-NC-ND 4.0

\section{REPOSITORY RECORD}

Kaminski, Piotr M., Ali Abbas, Sibel Yilmaz, Jake W. Bowers, and Michael Walls. 2019. "High Rate Deposition of Thin Film Cdte Solar Cells by Pulsed Dc Magnetron Sputtering”. figshare. https://hdl.handle.net/2134/20095. 


\title{
High rate deposition of thin film CdTe solar cells by pulsed dc magnetron sputtering
}

\author{
P.M. Kaminski *, A. Abbas, S. Yilmaz, J. W. Bowers and J.M. Walls \\ Centre for Renewable Energy Systems Technology, (CREST), \\ School of Electronic, Electrical and Systems Engineering, Loughborough University, \\ Loughborough, Leicestershire, LE11 3TU, UK \\ *Corresponding author: P.M.Kaminski@lboro.ac.uk
}

\begin{abstract}
A new high rate deposition method has been used to fabricate thin film CdTe photovoltaic devices using pulsed dc magnetron sputtering. The devices have been deposited in superstrate configuration on to a commercial fluorine doped tin oxide transparent conductor on soda lime glass. The cadmium sulphide and cadmium telluride thin films were deposited from compound targets. The magnetrons were mounted vertically around a cylindrical chamber and the substrate carrier rotates so that the layers can be deposited sequentially. The substrates were held at $200^{\circ} \mathrm{C}$ during deposition, a process condition previously found to minimize the stress in the coatings. Optimization of the process involved a number of parameters including control of pulse frequency, power and working gas pressure. The devices deposited using the process are exceptionally uniform enabling the CdTe absorber thickness to be reduced to $\sim 1 \mathrm{um}$. The asdeposited material is dense and columnar. The cadmium chloride treatment increases the grain size and removes planar defects. The microstructure of the films before and after activation has been characterized using a number of techniques including transmission electron microscopy, Energy Dispersive mapping and these measurements have been correlated to device performance. The deposition rate is much higher than can be obtained with radio-frequency sputtering and is comparable with methods currently used in thin film CdTe module manufacturing such as Vapour Transport Deposition and Close Space Sublimation.
\end{abstract}

\section{INTRODUCTION}

Photovoltaic (PV) modules are an increasingly important energy source. A total of 38.7GWp was installed globally in 2014. Thin film CdTe is an important technology and a financially viable alternative to the dominant c-Si technology. The potential of thin film CdTe PV technology is supported by recently reported significant improvements in the performance of the devices. First Solar Inc. has reported a new record cell conversion efficiency of $21.0 \%$ and a record module efficiency of $18.6 \%$ [1]. These efficiencies were achieved using manufacturing processes. The advantages of thin film CdTe solar cells lie in their low manufacturing costs and high energy yields. Currently, Vapour Transport Deposition (VTD) is used for depositing CdTe in the manufacturing of thin film CdTe solar panels. However, CdTe can be deposited by many other techniques including electro-deposition, evaporation, close space sublimation and magnetron sputtering [2]-[5]. Each of these techniques has some advantage either for the device performance or in the manufacturing process. The advantages of the magnetron sputtering process are the uniformity of the deposited layer, the high thin film density and the relatively low substrate temperatures used during the growth of the device. The sputter deposition of $\mathrm{CdTe}$ solar cell requires substrate temperatures of $\sim 250^{\circ} \mathrm{C}$ [6]-[9], compared to $400^{\circ} \mathrm{C}$ to $500^{\circ} \mathrm{C}$ reported for VTD [10], [11]. 
Until recently, radio-frequency (RF) power supplies were used exclusively to sputter CdTe films. DC power supplies are not suitable for the magnetron sputtering of CdTe thin films due to the dielectric nature of the targets. The disadvantages of using RF power lie in the complex system design and the slow deposition rates [12]. Recently we reported on a new process for the magnetron sputtering of CdTe [9]. This uses a pulsed DC power supply which overcomes many of the limitations of using RF power. Pulsed dc power has not been used previously since it is surprising that reliable process conditions can be established with such resistive targets. Pulsed dc magnetron sputtering is known to improve the microstructure of the deposited films [13]. It has also been demonstrated that the technique improves the quality of optical coatings due to increased deposition energy and the incorporation of surface diffusion during the 'off' part of the cycle [12]. Pulsed DC magnetron sputtering is a technology which has greatly simplified the deposition of semi-insulating materials and also provides commercially attractive deposition rates. Moreover, system design issues are greatly simplified [14]. The magnetron is driven by a Pulsed DC Voltage, the magnetron is biased at 300-800V for a fixed time after which the Voltage is reversed to positive values. Switching the Voltage neutralizes charging on the dielectric surfaces and prevents arcing. Depending on the process parameters, the duty cycle provides a significant advantage in deposition rate over the use of RF power supplies. The deposition rates are comparable to the rates obtained for the DC sputtering of metals.

\section{EXPERIMENT}

\section{Sample preparation}

The samples for the microstructural analysis were deposited on a NSG-Pilkington TEC10 glass substrate. Prior to the deposition, the substrate was cleaned in a $10 \%$ IPA in $18 \mathrm{M} \Omega$-cm DI water solution in an ultrasonic bath kept at $60^{\circ} \mathrm{C}$ for $60 \mathrm{~min}$. The cleaning stage was followed by a DI water rinse and drying. After the ultrasonic bath cleaning the sample surfaces were cleaned and activated by a vacuum plasma treatment (500W, Ar/N2 ambient for $5 \mathrm{~min}$ ).

The substrates were then loaded into a sputtering chamber for CdS and CdTe thin film deposition. A "PV Solar" pulsed DC magnetron sputtering system was used for the deposition. The system uses four $150 \mathrm{~mm}$ circular magnetrons which are mounted vertically around a cylindrical chamber. The substrates are mounted on a vertical carrier which rotates to provide coating uniformity. The system allows precise control of the position of the substrate carrier, to allow deposition of the film without rotation, if required. A pulsed DC power supply was used to form the plasma required for the sputtering process (Advanced Energy Inc. Pinnacle plus 5kW). The power supply was used in a constant power mode for the deposition. The pulsing frequency is adjustable in range up to $350 \mathrm{kHz}$, the duty cycle and target voltage can be adjusted using the reverse time setting. The depositions were carried out in an argon environment supplied through a mass flow controller rated at $100 \mathrm{sccm}$. The substrate temperature can be increase up to $500^{\circ} \mathrm{C}$ during the deposition of the sample if the substrate is stationary and $250^{\circ} \mathrm{C}$ if it is rotating.

\section{Characterization}

The film thickness was measured using a step height measurement with a stylus profilometer (Ambios XP2). The measurements were used to calculate the deposition rates. Samples for Transmission Electron Microscopy (TEM) were prepared by Focused Ion Beam (FIB) milling using a dual beam FEI Nova 600 Nanolab. A standard in situ lift out method was used to prepare cross-sectional samples through the coating into the glass substrate. A platinum over-layer was deposited to define the surface and homogenize the final thinning of the samples down to 100 $\mathrm{nm}$. TEM analysis was carried out using a Tecnai F20 operating at $200 \mathrm{kV}$ to investigate the 
detailed microstructures of the cell cross sections. The system was equipped with an Oxford instruments X-max N80 TLE SDD EDX detector and this was used in STEM mode to collect elemental distribution maps. These maps were collected in a single frame using a long dwell time and a small condenser aperture to minimize drift and beam spread during collection.

\section{RESULTS AND DISCUSSION}

A range of experiments were conducted from room temperature up to $400^{\circ} \mathrm{C}$ to measure the effect of substrate temperature on deposition rate. Samples were then prepared to study the effect of temperature on microstructure before and after $\mathrm{CdCl}_{2}$ activation. These samples were deposited without substrate heating and a second batch was deposited at a substrate temperature of $200^{\circ} \mathrm{C}$. The substrate carrier was rotated during both experiments. The depositions used $\mathrm{Ar}$ working gas at $7.5 \mu$ bar pressure. The samples were subsequently activated using $\mathrm{CdCl}_{2}$ in a vacuum evacuated tube furnace at $408^{\circ} \mathrm{C}$ for $8 \mathrm{~min}$.

\section{Deposition rate}

Step height measurements taken using a stylus profilometer were used to obtain the deposition rates of CdTe thin films as function of the substrate temperature. The measured deposition rates are plotted in Figure 1. Increase of the substrate temperature resulted in a decrease of the deposition rate. Without substrate heating a deposition rate of $2.8 \mathrm{~nm} / \mathrm{s}$ was measured; the equivalent static deposition rate reduced to $2 \mathrm{~nm} / \mathrm{s}$ at $200^{\circ} \mathrm{C}$ and $1.6 \mathrm{~nm} / \mathrm{s}$ at $400^{\circ} \mathrm{C}$ substrate temperature.

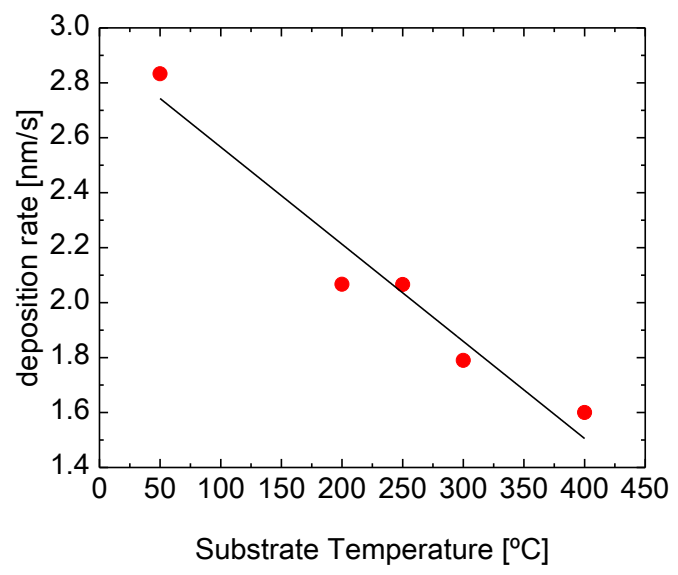

Figure 1 Static deposition rate measured for CdTe thin films deposited at different substrate temperatures.

\section{Microstructure}

A direct comparison of the crystalline grain structure of the deposited thin films is presented in Figure 2. The STEM cross section images are used to compare samples deposited without substrate heating and at a substrate temperature of $200^{\circ} \mathrm{C}$. Both thin films showed a columnar grain structure. The grains extended through the thickness of the sample. The sample deposited without substrate heating was characterized by a smaller grain diameter typically in the range $50 \mathrm{~nm}$ to $70 \mathrm{~nm}$ in diameter. The sample deposited at $200^{\circ} \mathrm{C}$ showed a similar grain structure but with larger grain diameter. Grains with diameter up to $250 \mathrm{~nm}$ were observed in the STEM image. The columnar grain structure and high grain boundary density provides fast diffusion channels for the $\mathrm{CdCl}_{2}$ treatment directly to the CdS/CdTe junction. Planar defects, predominantly stacking faults, were observed in the images of both samples prior to activation. Stacking faults are detrimental to the performance of thin film CdTe solar cells [15], [16]. These 
planar defects are always observed in as deposited thin film CdTe solar cells. They have been previously observed in thin films of CdTe using all other deposition methods. There is a direct correlation between the stacking fault density and the performance of the solar cell [15], [17].

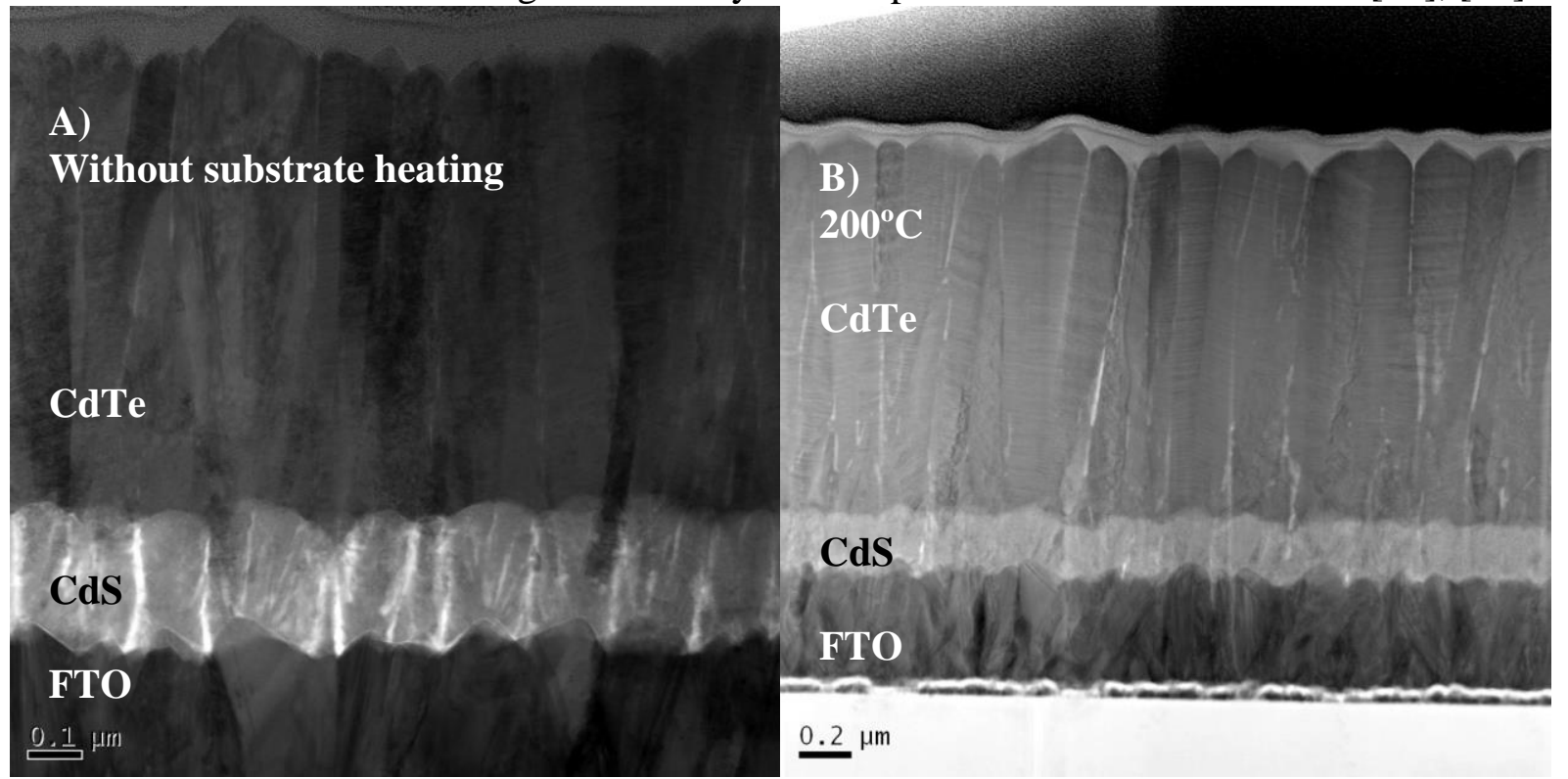

Figure 2 TEM images of cross-section of CdS/CdTe films deposited on a FTO coated glass: without substrate heating (A) and at $200^{\circ} \mathrm{C}(\mathrm{B})$. Planar defects are observed in the CdTe columns

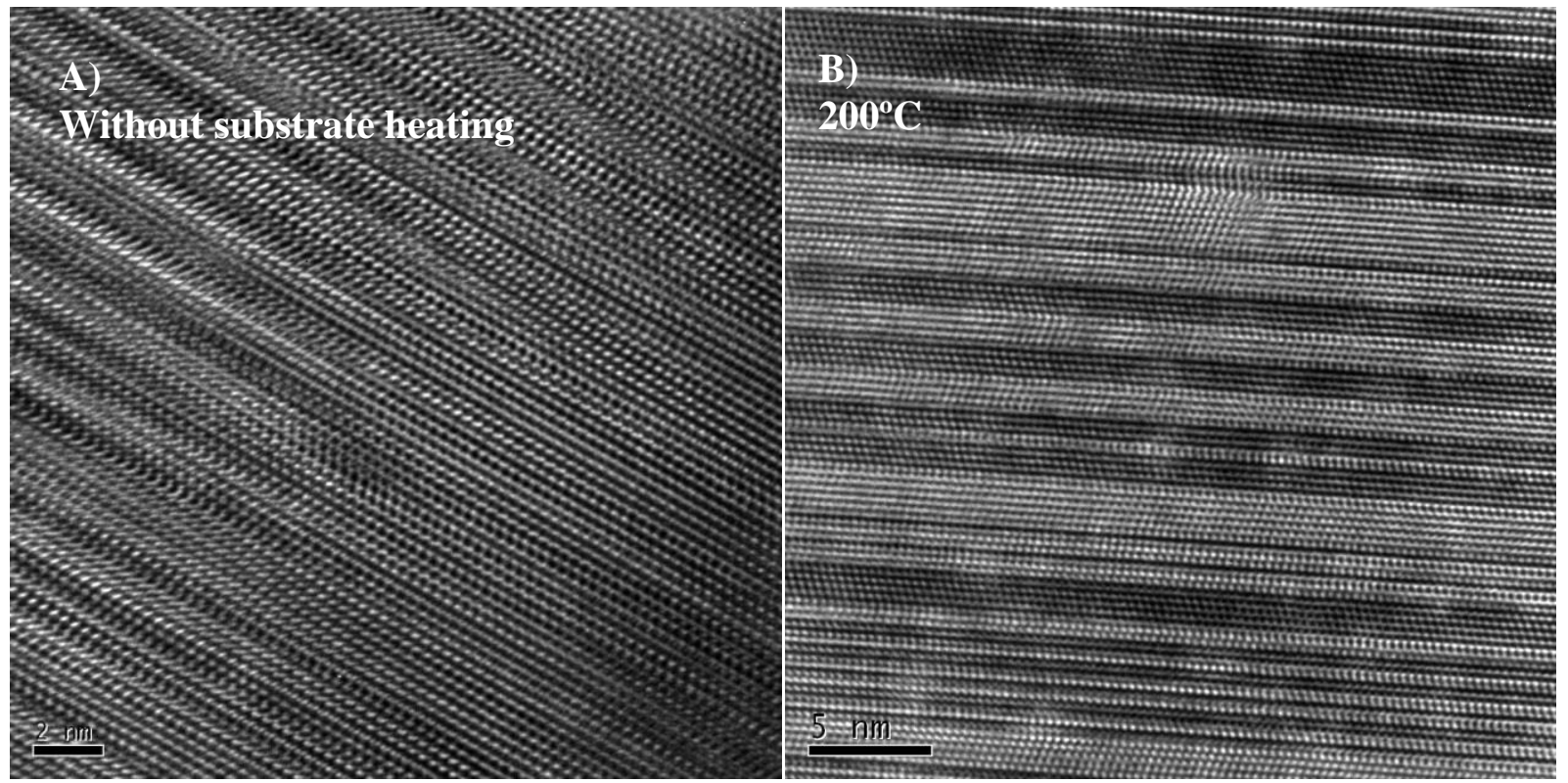

Figure 3 HR-TEM images of cross-section of CdTe films deposited: without substrate heating (A) and at $200^{\circ} \mathrm{C}(\mathrm{B})$. A high density of planar defects is clearly observed.

Figure 3 shows atomic scale resolution HRTEM images of the CdTe thin films sputtered using a pulsed DC magnetron power source. These high resolution images show the defects more clearly in the as-deposited films. The defect density in this film is higher than in the sample deposited at $200^{\circ} \mathrm{C}$. Figure 4 shows a STEM cross-section of the sample deposited at $200^{\circ} \mathrm{C}$ and then treated with $\mathrm{CdCl}_{2}$. The image shows that the stacking faults have been were removed by the treatment. Twin boundaries are observed but these are electrically neutral and are not detrimental to the 
performance of the CdTe solar cell [16], [17]. A dramatic change in the crystalline structure is observed, the long columnar grains extending through the sample are no longer present. The grains coalesce into larger grains with a more irregular shape. Also more distinct grains can be observed in the CdS thin film. Void formation after the $\mathrm{CdCl}_{2}$ treatment can be observed within the CdTe layer and at the junction. The EDX analysis of the sample shows that that chlorine decorates the grain boundaries of the $\mathrm{CdS}$ and $\mathrm{CdTe}$. This has been previously observed for a close space sublimated material [17].

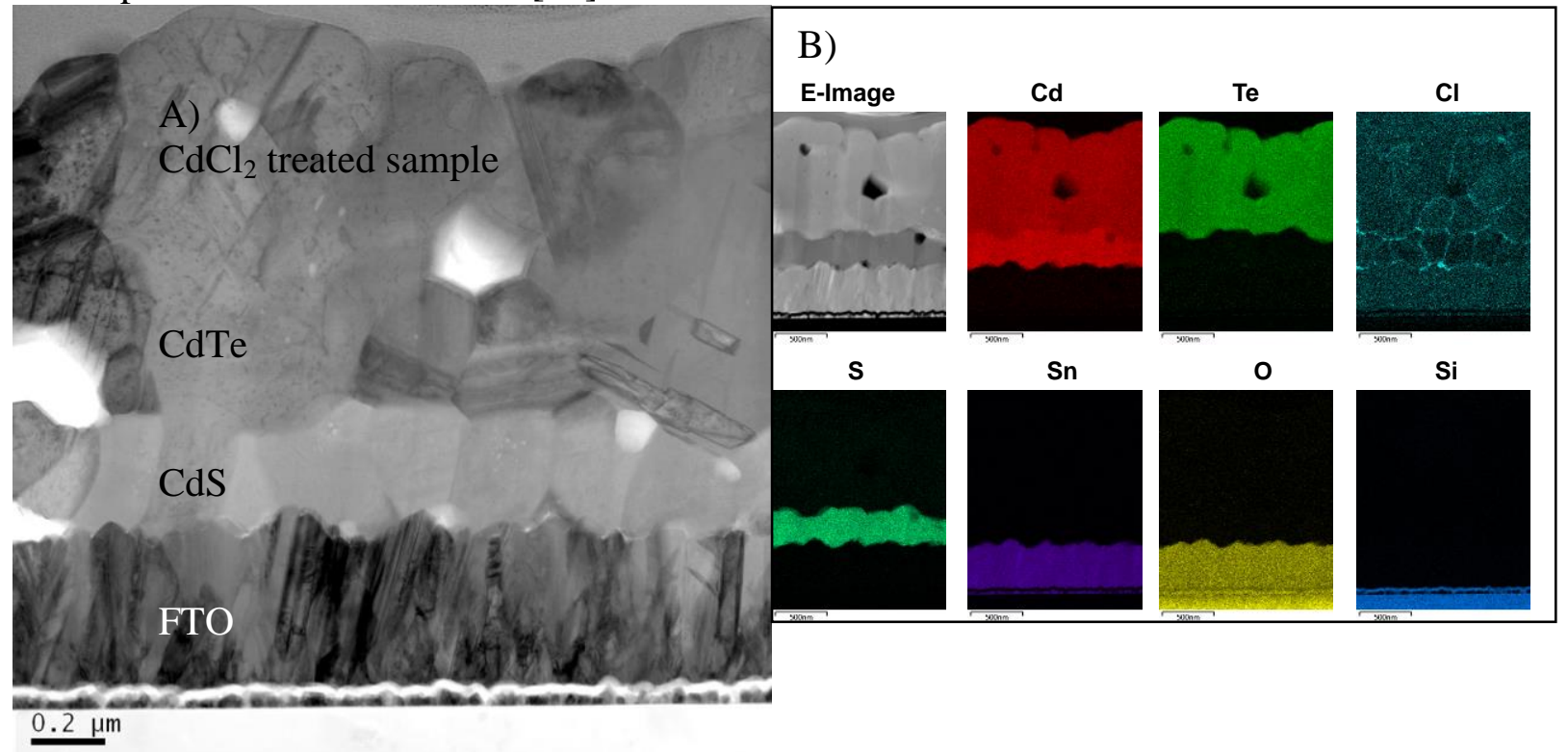

Figure 4 STEM cross-section image (A) and EDX elemental mapping (B) of a $\mathbf{C d C l}_{2}$ treated sample.

Figure 5 shows a cross section atomic scale resolution HRTEM image of the $\mathrm{CdCl}_{2}$ treated CdTe thin film. The image shows that the stacking fault defects have been removed. Twin boundaries are now observed.

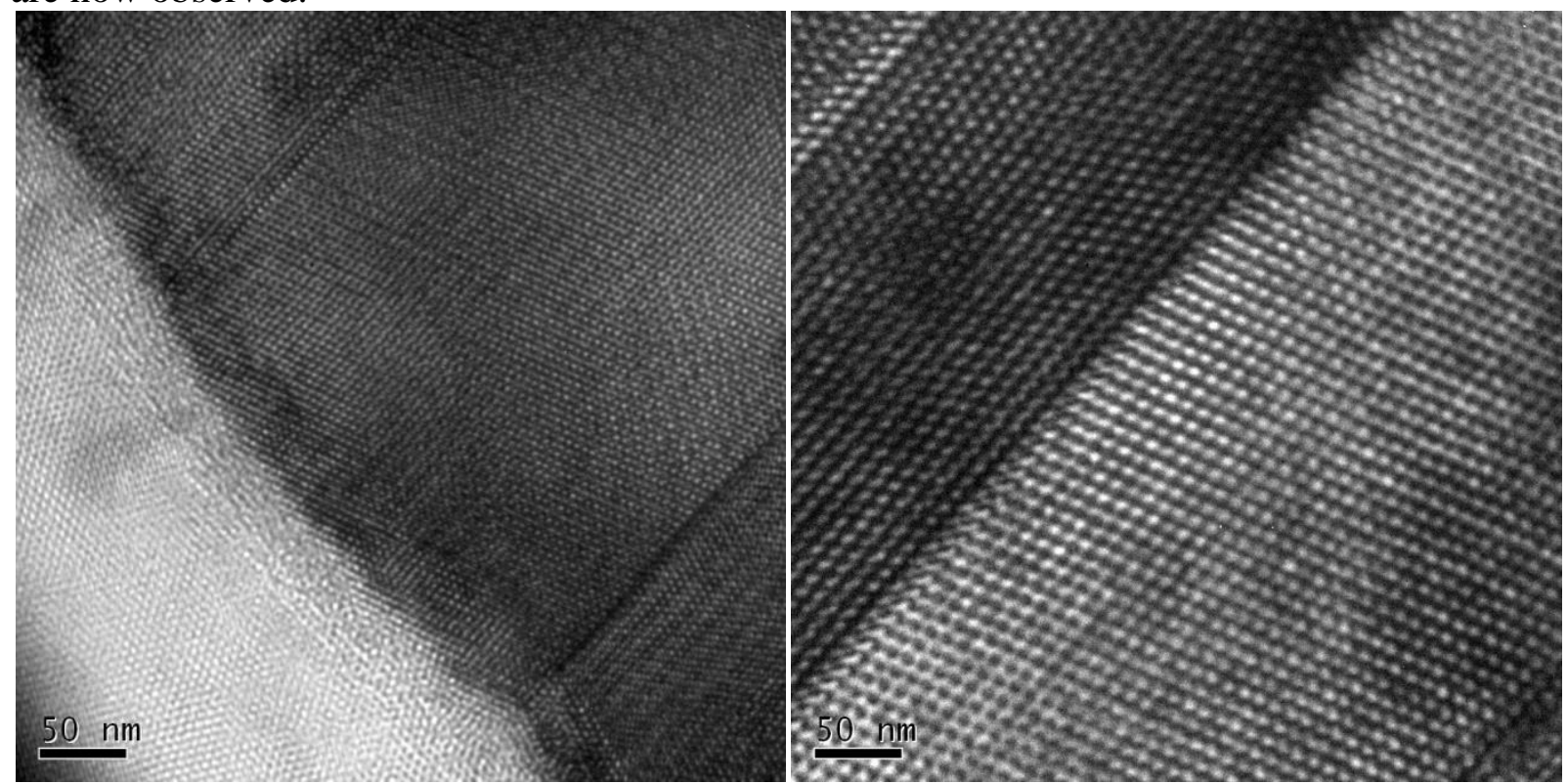

Figure 5 HR-TEM images of a $\mathrm{CdCl}_{2}$ treated CdTe film deposited by pulsed DC magnetron sputtering. Stacking faults have been removed and twin boundaries are now observed. 


\section{CONCLUSIONS}

Uniform thin film CdS and CdTe films have been successfully deposited at high deposition rates and under stable process conditions using pulsed DC magnetron sputtering. This is surprising due to the highly resistive nature of the compound targets used. Deposition rates up to $2.8 \mathrm{~nm} / \mathrm{s}$ were measured for unheated substrates. The deposition rate decreased to $2 \mathrm{~nm} / \mathrm{s}$ and $1.6 \mathrm{~nm} / \mathrm{s}$ for films deposited at $200^{\circ} \mathrm{C}$ and $400^{\circ} \mathrm{C}$ respectively. STEM analysis of the as deposited films showed that the sputtered films have a columnar structure, with grains extending through the thickness of the samples. The grains have diameters in the range 50nm-70nm for the thin films deposited without the use of substrate heating. When the substrate was heated to $200^{\circ} \mathrm{C}$ the grain diameter increased to $\sim 250 \mathrm{~nm}$. A high density of planar defects was observed in the as deposited material. This is consistent with previous observations of CdTe deposited using many other deposition methods. Lower defect density was observed in the thin films deposited at a substrate temperature of $200^{\circ} \mathrm{C}$. The analysis showed that the stacking faults, which are detrimental for the performance of the solar cell, were completely removed after the $\mathrm{CdCl}_{2}$ treatment. Chlorine decorates the grain boundaries of both the CdS and CdTe films in the activated material.

\section{REFERENCES}

[1] M. A. Green, K. Emery, Y. Hishikawa, W. Warta, and E. D. Dunlop, "Solar cell efficiency tables (Version 46)," Prog. Photovoltaics Res. Appl., vol. 23, pp. 805-812, 2015.

[2] W. Sampath, S. Kohli, R. A. Enzenorth, K. Barth, V. Manivannan, J. Hilfiker, P. R. McCurdy, K. Barricklow, and P. Noronha, "Advances in continuous, in-line processing of stable CdS/CdTe devices," in proceedings of IEEE 33rd PVSC, 2008, pp. 1-4.

[3] A. D. Compaan, A. Gupta, J. Drayton, S.-H. Lee, and S. Wang, "14\% sputtered thin-film solar cells based on CdTe," Phys. Status Solidi, vol. 241, no. 3, pp. 779-782, Mar. 2004.

[4] V. V Plotnikov, C. W. Carter, J. M. Stayancho, N. R. Paudel, H. Mahabaduge, D. Kwon, C. R. Grice, and A. D. Compaan, "Semitransparent PV Windows with Sputtered CdS / CdTe Thin Films," in proceedings of 39th IEEE PVSC, 2013, pp. 0405-0408.

[5] J. P. Enríquez and X. Mathew, "XRD study of the grain growth in CdTe films annealed at different temperatures," Sol. Energy Mater. Sol. Cells, vol. 81, pp. 363-369, 2004.

[6] N. R. Paudel, K. A. Wieland, and A. D. Compaan, "Ultrathin CdS/CdTe solar cells by sputtering," Sol. Energy Mater. Sol. Cells, vol. 105, pp. 109-112, Oct. 2012.

[7] R. E. Treharne, A. Seymour-Pierce, K. Durose, K. Hutchings, S. Roncallo, and D. Lane, "Optical Design and Fabrication of Fully Sputtered CdTe/CdS Solar Cells,” J. Phys. Conf. Ser., vol. 286, p. 012038, Mar. 2011.

[8] A. D. Compaan, A. Gupta, S. Lee, S. Wang, and J. Drayton, "High efficiency, magnetron sputtered CdS/CdTe solar cells," Sol. Energy, vol. 77, no. 6, pp. 815-822, Dec. 2004.

[9] P. M. Kaminski, A. Abbas, C. Chen, S. Yilmaz, F. Bittau, J. W. Bowers, and J. M. Walls, "Internal Stress Analysis of CdTe thin films Deposited by Pulsed DC Magnetron Sputtering," in proceedings of IEEE 42nd PVSC, 2015, submitted.

[10] M. J. Pavol, "Vapor Deposition Apparatus for Continuous Deposition of Multiple Thin Film Layers on a Substrate," US patent 29093599 B2, 2013.

[11] R. Garabedian, R. Malik, J. Theil, J. Trivedi, and M. Yu, "Vacuum Deposition System For Solar Cell Production And Method Of Manufacturing," 20150040970 A1, 2015.

[12] J. Musil, "Recent advances in magnetron sputtering technology," Surf. Coatings Technol., vol. 100-101, pp. 280-286, 1998.

[13] P. J. Kelly and R. D. Arnell, "Magnetron sputtering: a review of recent developments and applications," Vacuum, vol. 56, no. 3, pp. 159-172, Mar. 2000.

[14] A. Belkind, Z. Zhao, and D. Carter, "Pulsed-DC reactive sputtering of dielectrics: pulsing parameter effects," in proc. of 43rd Annual Technical Conference - Denver, SVC, 2000, pp. 86-90.

[15] A. Abbas, G. West, J. Bowers, P. Isherwood, P. M. Kaminski, B. Maniscalo, P. Rowley, J. M. Walls, K. Barricklow, W. Sampath, and K. Barth, "The Effect of Cadmium Chloride Treatment on Close-Spaced Sublimated Cadmium Telluride Thin-Film Solar Cells," IEEE J. Photovoltaics, vol. 3, no. 4, pp. 1361-1366, Oct. 2013.

[16] S. H. Yoo, K. T. Butler, A. Soon, A. Abbas, J. M. Walls, and A. Walsh, "Identification of critical stacking faults in thinfilm CdTe solar cells," Appl. Phys. Lett., vol. 105, p. 062104, 2014.

[17] A. Abbas, G. D. West, J. W. Bowers, P. M. Kaminski, B. Maniscalco, J. M. Walls, K. L. Barth, and W. S. Sampath, "Cadmium chloride assisted re-crystallization of CdTe: The effect of annealing over-treatment," in proceedings of IEEE 40th PVSC, 2014, pp. 701-706. 